\title{
Zakażenia hantawirusami ze szczególnym uwzględnieniem populacji europejskiej i ich obraz kliniczny na tle innych gorączek krwotocznych
}

\begin{abstract}
STRESZCZENIE
$\mathbf{H}$ antawiusy należą do rodziny Bunyaviridae. Powodują one dwie niebezpieczne dla człowieka choroby: w Azji i Europie gorączkę krwotoczną z zespołem nerkowym (HRFS), a w obu Amerykach tak zwany hantawirusowy zespół płucny (HCPS). Większość hantawirusów przenoszona jest przez gryzonie, niemniej jednak jako rezerwuar hantawirusów opisywane są również inne małe ssaki. Infekcje hantawirusowe są trudne do rozpoznania z powodu objawów klinicznych podobnych jak przy infekcjach wywołanych przez inne wirusy gorączek krwotocznych.
\end{abstract}

\section{WPROWADZENIE}

Rodzaj Hantavirus stanowią wirusy RNA należące do rodziny Bunyaviridae, która obejmuje również cztery inne rodzaje: Nairovirus, Orthobunyavirus, Phlebovirus i Tospovirus. Ponieważ do dnia dzisiejszego zidentyfikowano ponad 300 wirusów, występujących na całym świecie, a należących do tej rodziny, stanowią one realne, globalne zagrożenie dla zdrowia publicznego [1]. W odróżnieniu od pozostałych Bunyaviridae rezerwuarem hantawirusów nie są stawonogi [2].

Hantawirusy, podobnie do kilku innych wirusów powodujących zoonozy, trwale zakażają swoje naturalne rezerwuary, nie powodując u nich oznak choroby, jednak u ludzi wywołują różne objawy kliniczne, w tym schorzenia o zróżnicowanym wskaźniku umieralności [3,4]. Choć obecność hantawirusów została potwierdzona na większości kontynentów, to odmienne gatunki tych wirusów charakteryzuje różny obszar występowania [5].

Naturalnym rezerwuarem dla hantawirusów są gryzonie, takie jak nornice, myszy, chomiki czy szczury, jednak coraz częściej opisywane są w literaturze przypadki gospodarzy pod postacią ryjówek, kretów oraz nietoperzy $[2,6,7]$. Ponadto istnieją doniesienia o seropozytywnych zwierzętach domowych, takich jak psy i koty, które mogły ulec zakażeniu w wyniku kontaktu z zakażonymi pierwotnymi gospodarzami [7]. Każdy z hantawirusów związany jest z odrębnym gatunkiem gryzonia [6]. Hantawirusy, które zostały zidentyfikowane w Europie i Azji, należą do hantawirusów Starego Świata i są one przenoszone przez cztery rodzaje gryzoni: Myodes, Microtus, Apodemus i Rattus, a także przez dwie rodziny owadożernych: Soricidae i Talpidae. Najbardziej rozpowszechnionym rezerwuarem jest nornica ruda (Myodes glareolus), która jest nosicielem wirusa Puumala [8].

Transmisja wirusa odbywa się drogą powietrzną poprzez wdychanie aerozoli pochodzących z moczu, kału lub śliny zakażonego zwierzęcia, ale może również być wynikiem ukąszeń przez zakażone zwierzęta [7].

\section{ODPOWIEDŹ IMMUNOLOGICZNA NA ZAKAŻENIE WIRUSOWE}

Infekcja wirusowa aktywuje wrodzoną odpowiedź immunologiczną, której celem jest zmniejszenie wirusowej replikacji [9]. Odpowiedź immunologiczna może być aktywowana natychmiast po rozpoznaniu patogenu przez receptory rozpoznające patogeny (ang. pathogen recognition receptors; PRRs). Wśród różnych receptorów uczestniczących $\mathrm{w}$ wykrywaniu patogenów, receptory TLR (ang. toll-like receptor; receptory toll-podobne) odgrywają ważną rolę w szlakach wrodzonej odpowiedzi immunologicznej. TLR aktywując szereg szlaków sygnałowych powoduje uwalnianie cytokin zapalnych i interferonu typu I [10]. Interferon typu I (IFN) odgrywa kluczową rolę w mechanizmie odpowiedzi immunologicznej, zapewniając ochronę antywirusową i aktywację komórek wrodzonej odpowiedzi immunologicznej, jakimi są naturalne komórki cytotoksyczne (ang. natural killers; NK) [9]. Wirusowy dsRNA lub fragmenty RNA są roz- mgr Kamila Julia Stopnicka,

dr n. med. Szymon Walter de Walthoffen,

\section{dr hab. n. med. Tomasz Dzie- ciątkowski $^{\square}$}

Katedra i Zakład Mikrobiologii Lekarskiej, Warszawski Uniwersytet Medyczny, ul. Chałubińskiego 5, 02-004 Warszawa

https://doi.org/10.18388/pb.2020_356

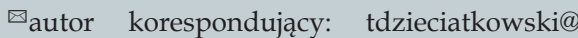
wum.edu.pl

Słowa kluczowe: hantawirusy, zakażenia wirusowe, gorączki krwotoczne, metody diagnostyczne, zoonozy

Skróty: AMRV - wirus Amur, ANDV - wirus Andes, CARDs - domeny aktywacji i rekrutacji kaspaz, DOBV - wirus Dobrava-Belgrad, HCPS - hantawirusowy zespół sercowo-płucny, HFRS - gorączka krwotoczna z zespołem nerkowym, IRF3 - czynnik 3 regulujący interferon, MAVS - mitochondrialne antywirusowe białko sygnalizacyjne, PUUV - wirus Puumala, PRRs - receptory rozpoznające patogeny, SAAV - wirus Saarema, SEOV - wirus Seoul, SNV - wirus Sin Nombre, STING - stymulator genów interferonowych, TLR - receptory toll-podobne, TULV - wirus Tula, VEGF - czynnik wzrostu śródbłonka naczyniowego, VHF - wirusowe gorączki krwotoczne 
poznawane przez receptory TLR, które kierują kaskadami sygnałowymi w komórce gospodarza prowadzącymi do indukcji INF typu I (a i $\beta$ ). Cytoplazmatyczne receptory RIG-I oraz MDA5 wykrywają wirusowy RNA i aktywują domeny CARDs (ang. caspase activation and recruitment domains; domeny aktywacji i rekrutacji kaspaz). CARDs odpowiadaja za bezpośrednie interakcje z MAVS (ang. mitochondria antiviral-signaling protein; mitochondrialne antywirusowe białko sygnalizacyjne), jak i gromadzenie kompleksów kaskady sygnałowej. Po aktywacji MAVS wywołuje dalszą aktywację, fosforylację i dimeryzację zlokalizowanego w retikulum endoplazmatycznym białka STING (ang. stimulator of interferon genes; stymulator genów interferonowych). STING jest białkiem, które wiąże kompleksy kinazy TBK1 poprzez swoją cytoplazmatyczną domenę C-końcową. Po związaniu z STING, TBK1 fosforyluje czynniki IRF3 (ang. interferon regulatory factor 3; czynnik 3 regulujący interferon) i IKB, powodując tworzenie dimerów fosfo-IRF3 i aktywację NF-kB (ang. nuclear factor kappa-light-chain-enhancer of activated $B$ cells). IRF3 i NF-kB przemieszczają się do jądra, gdzie następuje transkrypcja INF- $\beta$. Po indukcji, IFN- $\beta$ jest wydzielany przez EC (ang. endothelial cells; komórki śródbłonka) i wiąże się $\mathrm{z}$ receptorami IFN (ang. interferon- $a / \beta$ receptor; IFNAR), aktywując tym samym kinazy JAK (ang. Janus-activated kinases). Kinazy JAK fosforylują białka STAT (ang. signal transducer and activator of transcription; białka przetworniki sygnału i aktywatory transkrypcji), co prowadzi do indukcji czynników aktywujących dalsze ścieżki sygnałowe, dzięki którym możliwa jest indukcja IFN i wzmożona transkrypcja genów stymulowanych przez interferon (ang. interferon stimulated genes; ISG) [11].

W celu przetrwania hantawirusy rozwinęły mechanizmy unikania odpowiedzi immunologicznej, często poprzez hamowanie szlaków aktywujących transkrypcję IFN [9]. Kluczową rolę w unikaniu odpowiedzi immunologicznej przez hantawirusy odgrywa glikoproteina Gn. Zawiera ona długi cytoplazmatyczny koniec (Gn-T), który rekrutuje w cytoplazmie białka wirusowe i komórkowe. Gn-T blokuje wiązanie pomiędzy TBK1-TRAF3 i STING-TBK1, hamując tworzenie kompleksu STING-PBK1-IRF3 i aktywację NF-kB. Specyficzne interakcje między Gn-T a białkiem STING i kinazą TBK1 nie są do końca poznane [11]. Niepatogenne hantawirusy nie posiadają zdolności hamowania indukcji INF [9].

\section{CHOROBOTWÓRCZOŚĆ HANTAWIRUSÓW}

Głównym zjawiskiem stojącym za patogenezą gorączki krwotocznej z zespołem nerkowym (ang. hemorrhagic fever with renal syndrome; HFRS) czy hantawirusowego zespołu sercowo-płucnego (ang. Hantavirus cardiopulmonary syndrome; HCPS) jest wzrost przepuszczalności śródbłonka naczyniowego i ostra trombocytopenia [8]. Zwiększona przepuszczalność naczyń obserwowana w zakażeniach patogennymi hantawirusami jest zdarzeniem wieloczynnikowym. Silna odpowiedź immunologiczna i uwolnienie czynników przepuszczalności mogą przyczyniać się do zwiększonej przepuszczalności naczyń. Również infekcja wirusowa śródbłonka może inicjować wyciek naczyniowy i kaskadę sygnalizacji komórkowej prowadzącą do hiperprzepuszczalności naczyń [12]. W porównaniu z innymi gorączkami krwotocznymi, które hamują dojrzewanie za- każonych komórek dendrytycznych (ang. dendritic cell; DC), hantawirusy indukują ich dojrzewanie i tak wywołują silną odpowiedź komórkową podczas ostrej infekcji [8].

Zakażenie komórek śródbłonka przez hantawirusy nie powoduje efektu cytopatycznego zarówno w warunkach in vitro jak i in vivo, co doprowadziło do hipotezy, że odpowiedzialna za patogenezę jest silna odpowiedź immunologiczna $[7,9,13]$. Zainfekowane monocyty i makrofagi wytwarzają dodatkowe chemokiny, cytokiny i inne cząsteczki prozapalne, jak TNF-a (ang. tumor necrosis factor; czynnik martwicy nowotworu) i reaktywne formy tlenu/azotu [12]. Zwiększony poziom cytokin i chemokin oraz brak równowagi przy ich wytwarzaniu przyczyniają się do zwiększenia przepuszczalności śródbłonka naczyniowego, a tym samym do ciężkiego przebiegu choroby [4,10]. Adaptacyjny układ odpornościowy, który składa się z cytotoksycznych limfocytów T i limfocytów B, wytwarza swoiste przeciwciała. Chociaż te odpowiedzi są kluczowe dla odpowiedzi immunologicznej mogą również prowadzić do uszkodzeń komórek gospodarza, jeśli nie są odpowiednio regulowane [4].

Silna reakcja limfocytów T obejmuje wytworzenie cytotoksycznych komórek CD8 i w mniejszym stopniu CD4 [4]. Istnieją jednak różne typy komórek CD8 o różnych mechanizmach efektorowych, w tym cytolityczne i niecytolityczne, które przyczyniają się do odporności na infekcję wirusową [13]. Komórki CD4 po rozpoznaniu antygenów, różnicują się na co najmniej dwie podgrupy komórek pomocniczych - Th1 i Th2 [8,15]. Komórki Th1 wytwarzają IFN-ү i TNF- $\beta$. Komórki Th2 wytwarzają interleukiny IL-4 i IL-5 oraz rozwijają odpowiedź humoralną i alergiczną. Indukowane regulatory limfocytów T wytwarzających IL-10 i TGF-a (ang. transforming growth factor; transformujaccy czynnik wzrostu) odgrywają ważną rolę $\mathrm{w}$ regulowaniu odpowiedzi immunologicznej i patologii wywołanej infekcją $[4,8]$.

Cytokiny, takie jak TNF-a, IL-6 i IL-1, pełnią funkcje mediatorów, które wywołują gorączkę, wstrząs septyczny. TNF-a, IFN- $\beta$ i IL-6 są cytokinami, które odpowiadają za zwiększona przepuszczalność komórek śródbłonka [4,10]. Nadprodukcja TNF-a może powodować do toksyczności ogólnoustrojowej. W warunkach in vitro TNF-a może prowadzić do zwiększonej przepuszczalności pojedynczej warstwy komórek śródbłonka bez widocznego efektu cytopatycznego [10]. Infekcja śródbłonka naczyniowego i wczesne wydzielanie VEGF (ang. vascular endothelial growth factor; czynnik wzrostu śródbłonka naczyniowego) powoduje przerwanie połączeń i deregulację VE-kadheryny, która odpowiada za połączenia międzykomórkowe. Fosforylacja w obrębie VE-kadheryny powoduje odłączenie fragmentów sąsiadujących dimerów VE-kadheryny, a to z kolei jest przyczyną pojawienia się międzykomórkowych szczelin [7]. W warunkach in vivo VEGF jest wydzielany przez inaktywowane wirusami komórki T, płytki krwi i makrofagi. W tych warunkach czynniki przenikalności (TNF-a i/lub VEGF) osiągają wysokie stężenia w mikrokrążeniu płuc, powodujące nadmierną przepuszczalność naczyń [12].

Wzrost poziomu IL-10, INF-ץ i TNF-a został wykryty u pacjentów z infekcją wirusem Dobrava-Belgrade (DOBV) i Puumala (PUUV). Znacząco poniesione poziomy IL-10 i 
TNF-a wystąpiły u pacjentów z cięższym przebiegiem klinicznym. Bardziej dotkliwa postać nefropatii epidemicznej (NE) charakteryzuje się podniesionym poziomem prozapalnych cytokin IL-6 i TNF-a, ale również spadkiem poziomu TGF- $\beta$. U pacjentów z NE cytotoksyczne komórki T mogą przyczyniać się do uszkodzeń naczyń włosowatych poprzez immunopatologie, ale również przez zwiększenie koncentracji tlenku azotu i TGF-a [8]. Wykryto kilka cytokin, szczególnie w tkance płucnej od pacjentów ze śmiertelnym HCPS, w tym tych potencjalnie wytwarzanych przez limfocyty T, takich jak TNF-a, IL-2, IL-6 i IFN-ץ. Zarówno TNF-a, jak i IL-2 mogą zwiększać przepuszczalność naczyń [12].

Czynniki jądrowe i transkrypcyjne w zakażonych komórkach różnią się w zależności od rodzaju hantawirusa. Zakażenie aktywuje czynniki transkrypcyjne takie jak: IRF7, IRF-1 czy IRF-9. Aktywność tych czynników jest mniejsza w zakażeniach niepatogennymi hantawirusami. Dla aktywności IRF-3 kluczowa jest translokacja jądrowa, która obejmuje aktywacje cytokin oraz IFN. IRF-3 aktywację cytokin oraz IFN. IRF-3 kontroluje aktywację transkrypcji genów chemokin CCL5, podczas gdy IRF-1 i IRF-3 regulują ekspresje białka MxA. Białko MxA jest kluczowym mediatorem przeciwwirusowego działania IFN typu I, zapewniającego odporność na szeroki zakres wirusów RNA. Istnieją dwa rodzaje białek Mx u ludzi: MxA i MxB, przy czym tylko MxA wykazuje aktywność przeciwwirusową. W zainfekowanych komórkach występuje zwiększony poziom CCL5 i MxA. Dlatego można stwierdzić, że indukowane przez hantawirusy IRF-1 i 3 mogą prowadzić do zmian w ekspresji cytokin i INF w zakażonych komórkach [9].

Ludzkie geny HLA kodujące główny układ zgodności tkankowej (ang. major histocompatibility complex; MHC) klasy I zostały skorelowane z łagodnym lub ciężkim przebiegiem infekcji hantawirusowej. Genetyczna predyspozycja do ciężkiego przebiegu choroby HFRS również jest związana $\mathrm{z}$ typem HLA, jednak różne hantawirusy są związane $\mathrm{z}$ różnymi haplotypami. Ciężka postać HFRS spowodowana zakażeniem PUUV związana jest w szczególności z haplotypem HLA-B*8 [16]. Ten sam haplotyp HLA jest skorelowany z ciężkim przebiegiem HCPS po zakażeniu wirusem Andes (ANDV). Allel HLA-B*35, u zakażonych ANDV, wykryto u pacjentów z łagodną postacią choroby HCPS [12]. Haplotyp HLA-B*35 występuje częściej w ciężkim postępie choroby u pacjentów zakażonych wirusem DOBV, zwłaszcza w przypadkach śmiertelnych [8]. U pacjentów z HCPS zakażonych wirusem Sin Nombre (SNV) allel HLA-B*35 jest związany z ciężkimi przypadkami choroby $[7,8,12]$.

\section{OBRAZ KLINICZNY GORĄCZKI KRWOTOCZNEJ Z ZESPOŁEM NERKOWYM (HFRS)}

Zakażenie wirusami powodującymi gorączkę krwotoczną z zespołem nerkowym (ang. hemorrhagic fever with renal syndrome; HFRS) mogą przebiegać z różnym nasileniem objawów, w zależności od rodzaju wirusa powodującego zakażenie. Obraz kliniczny HFRS manifestuje się od łagodnych objawów do zakażeń o ciężkim przebiegu. HFRS wywołane przez wirusy Puumala (PUUV) i Saarema (SAAV) charakteryzują się łagodnym przebiegiem i niskim poziomem śmiertelności $(<1 \%)$. Zakażenia powodowane przez wirusa Amur (AMRV) i DOBV mają zazwyczaj ciężki przebieg z wyższym poziomem śmiertelności (5-15\%).

Przebieg kliniczny choroby hantawirusowej można podzielić na następujące stadia: gorączka, hipotensja, oliguria, poliuria i stadium rekonwalescencji. W zakażeniach spowodowanych przez AMRV i DOBV objawy kliniczne są bardziej nasilone niż w zakażeniach wywołanych przez wirusa Seoul (SEOV). Okres inkubacji trwa od 2 do 4 tygodni $[10,15]$. Objawy takie jak: wysoka gorączka, dreszcze, bóle głowy, ból w okolicy nerek, bóle brzucha, nudności i wymioty pojawiają się gwałtownie $[5,17]$. Odnotowano również występowanie senności i zaburzenia widzenia $[8,13]$. Pierwsze stadium trwa zazwyczaj od 3 do 7 dni, w którym pod koniec okresu pojawiają się drobne, punktowe wybroczyny na podniebieniu i wylewy dospojówkowe. Stadium hipotensyjne może trwać od kilku godzin do 2 dni. W ciężkich przypadkach szybko się rozwija niedociśnienie i szok hipowolemiczny. Na tym etapie $1 / 3$ zgonów wiąże się z nagłym wstrząsem. Charakterystyczna jest małopłytkowość, leukocytoza i krwotoki. Objawy krwotoczne mogą obejmować: wybroczyny na skórze, błonie śluzowej i spojówkach, krwotoki z nosa, krwawe wymioty, krwiomocz i ciężkie krwotoki wewnątrzczaszkowe. Stadium oligurii trwa od 3 do 7 dni. Ciśnienie krwi normuje się, jednak funkcje nerek są przejściowo ograniczone, co prowadzi do skąpomoczu lub nawet bezmoczu, białkomoczu, zaburzeń w osadzie moczu, włącznie z krwiomoczem mikroskopowym i azotemią. Podczas tego stadium, zwykle występuje ból brzucha lub okolic nerek [8]. Pacjenci z ciężkimi objawami muszą być leczeni za pomocą hemodializ [15]. Wyniki badań laboratoryjnych wskazują podwyższone stężenie kreatyniny i mocznika w surowicy. Połowa zgonów jest związana ze stadium, w którym dochodzi do skąpomoczu [10,15]. Podczas poliurii czynności nerek i dróg moczowych zaczynają powracać i zwiększa się ich wydajność, co stanowi pozytywne rokowanie dla pacjenta. Czas trwania choroby waha się od kilku dni do kilku tygodni, choć sam proces rekonwalescencji jest długi i może trwać do 6 miesięcy [8]. U dzieci, w odróżnieniu od osób dorosłych, obraz kliniczny choroby wywołanej przez hantawirusy charakteryzuję się łagodniejszym przebiegiem [8].

\section{OBRAZ KLINICZNY HANTAWIRUSOWEGO ZESPOŁU SERCOWO-PŁUCNEGO (HCPS)}

W porównaniu do HFRS, hantawirusowy zespół sercowo-płucny (HCPS) ma cięższy i bardziej gwałtowny przebieg. Odsetek zgonów wynosi od około 30 do 50\%. Średni okres inkubacji po ekspozycji do początku objawów wynosi 18-19 dni, wahając się od 11 do 32 dni (ANDV) i od 9 do 33 dni dla hantawirusa Sin Nombre [18].

Obraz kliniczny występuję w trzech stadiach [20]. Pierwsze stadium choroby, w której dochodzi do pierwszych manifestacji objawów choroby jest zazwyczaj krótkie i niespecyficzne. Podobnie jak w HFRS charakteryzuje się ono niespecyficznymi objawami grypopodobnymi, takimi jak: gorączka, dreszcze, ból głowy, ból mięśni, ból brzucha, nudności, wymioty i biegunka $[7,20]$. Drugie stadium choroby 
to stadium krążeniowo-oddechowe, w którym początkowo występuje kaszel, duszności i częstoskurcz. Następnie u zakażonych pacjentów gwałtownie rozwija się ostry niekardiogenny obrzęk płuc, spowodowany wyciekiem z naczyń włosowatych i niedociśnienie tętnicze. Szybko rozwijające się obustronne nacieki (czasami związane z wysiękiem opłucnowym) powodują niewydolność oddechową [8,21]. W ciężkich przypadkach następuje kwasica mleczanowa, hemokoncentracja i wstrząs kardiogenny, który jest główną przyczyną zgonu $[7,18]$. Występują również objawy krwotoczne, takie jak hematuria czy krwawienie jelitowe.

Obraz laboratoryjny obejmuje trombocytopenię, leukocytozę lub leukopenię, wysokie miano hematokrytu i limfocytów obwodowych, nieprawidłowe wyniki prób wątrobowych, łagodny wzrost kreatyny, hiponatremię i białkomocz [7].

Stale rosnąca liczba przypadków gorączek krwotocznych z zespołem nerkowym z udziałem niewydolności płuc i liczba przypadków hantawirusowego zespołu płucnego z zaburzeniami czynności nerek doprowadziła do wniosku, że objawy obu zespołów częściowo się pokrywają [22,24].

\section{RÓŻNICOWANIE Z INNYMI CZYNNIKAMI ETIOLOGICZNYMI GORĄCZEK KRWOTOCZNYCH}

Czynnikami etiologicznymi wirusowych gorączek krwotocznych są 4 rodziny wirusów: Arenaviridae, Bunyaviridae, Filoviridae, i Flaviviridae, które także wywołują choroby odzwierzęce [24,25]. Okres wylęgania chorób wywoływanych przez wirusy gorączek krwotocznych może wynosić od kilku dni do kilku tygodni. Obraz kliniczny zależy od rodzaju wirusa i od jego tropizmu narządowego $[17,26]$.

Odpowiednia diagnoza jest istotnym czynnikiem w leczeniu chorób wirusowych. Niemniej jednak infekcje wirusowe są trudne do odróżnienia, szczególnie na samym początku [27]. Rozpoznanie wirusowych gorączek krwotocznych opiera się na wywiadzie, obrazie klinicznym, a także diagnostyce laboratoryjnej osób chorych, które powróciły lub przebywają $\mathrm{w}$ rejonach endemicznego występowania VHF (ang. viral hemorrhagic fevers; wirusowe gorączki krwotoczne) [17]. Diagnostyka laboratoryjna bazuje na izolacji patogenu z materiału biologicznego, w tym krwi, moczu i śliny, przy użyciu metod biologii molekularnej lub metod serologicznych $[17,28]$.

Izolacja wirusów z surowicy, osocza i innych płynów ustrojowych może być przeprowadzana tylko w laboratorium BSL-3 i 4 [29]. Mikroskopia elektronowa (ang. electron microscopy; EM) może być użyta do identyfikacji wirusa na podstawie cech strukturalnych z materiałów klinicznych. Hodowla wirusów w warunkach in vitro pozostaje wciąż pomocna w charakteryzowaniu nowych wirusów lub ich odmienności, jednak przygotowanie próbek dla EM wymaga dostępu do wysoce wyspecjalizowanych laboratoriów, a zakończenie tych procedur może być długotrwałe. W rezultacie metody te nie są już stosowane jako pierwsza linia diagnostyczna [30].
Badanie immunoenzymatyczne (ang. enzyme-linked immunosorbent assay; ELISA) to jedna $\mathrm{z}$ najczęściej wykorzystywanych metod wykrywania przeciwciał IgG $i$ IgM. Jednak metody serologiczne nie są miarodajne $\mathrm{w}$ diagnozowaniu ostrych zakażeń VHF, ponieważ obecność przeciwciał klasy IgM może wskazywać na różne stadia zakażenia, w tym wcześniejsze zakażenia objawowe i nie objawowe. Rozpoznanie niedawnego zakażenia VHF może wymagać dodatkowych pobrań krwi w celu ustalenia czy pacjent ma podwyższone miano przeciwciał IgM. Diagnostyka serologiczna często nie jest specyficzna z powodu częstych reakcji krzyżowych między blisko powiązanymi wirusami, zwłaszcza wśród Bunyaviridae i Flaviviridae. Pomimo problemów związanych z metodami serologicznymi, w tym reakcjami krzyżowymi, metody te są złotym standardem przy wykrywaniu Bunyaviridae [30].

Wykrywanie kwasu nukleinowego stało się powszechnym narzędziem diagnostycznym chorób wirusowych, w tym VHF. Testy RT-PCR opracowano dla większości wirusów VHF. Jednak wykrywanie jednego patogenu za pomocą tej metody, miało ograniczenia na obszarach, w których występuje endemicznie więcej niż jeden wirus VHF. W 2002 roku wprowadzono multiplex-PCR, z możliwością wykrycia różnych wirusów gorączek krwotocznych, który ma czułość i swoistość porównywalną z RT-PCR [30]. Zmodyfikowane techniki amplifikacji kwasów nukleinowych, takie jak nested PCR lub semi-nested PCR, mogą zwiększyć czułość i swoistość. Detekcja filowirusów metodą PCR opiera się na wykrywaniu wysoko konserwatywnego genu kodującego polimerazę oraz genu glikoproteiny do wykrywania wszystkich podtypów wirusa Eboli (z wykluczaniem wirusa Marburg), jak i genu kodującego nukleoproteiny [29]. Wirus krymsko-kongijskiej gorączki krwotocznej wykrywa się poprzez skierowanie na segment S RNA, a wirus gorączki doliny Rift na segmenty M i S. Czułość testów do wykrywania buniawirusów (66-70\%) nie jest tak wysoka, jak w przypadku filowirusów (blisko 100\%).W przypadku arenawirusów celem jest segment S RNA. Jednakże ten segment jest bardzo zmienny, do wykrycia wszystkich szczepów potrzebnych jest kilka starterów wykorzystywanych w metodzie PCR. Zaprojektowane zostały również startery dla segmentu L. Startery wirusa żółtej gorączki (flawiwirus) są skierowane na wysoce konserwatywny gen NS5 [29].

Aptamery to cząsteczki jednoniciowego kwasu nukleinowego, składające się z DNA lub RNA, które wiążą się z cząsteczkami organicznymi lub nieorganicznymi - od pojedynczych atomów do szerokiego zakresu białek. Charakteryzują się wysoką specyficznością wobec cząsteczki docelowej i powinowactwem wiązania [27]. Aktualne badania nad ich wykorzystaniem $\mathrm{w}$ terapii chorób wirusowych nie są wystarczająco rozwinięte. Są one głównie skupione na dobrze znanych wirusach, takich jak HIV-1, HCV, HBV, HPV, SARS-CoV i grypa. Badania na temat innych wirusów nie są przeprowadzane systematycznie. Dobrym przykładem są okazjonalnie przeprowadzone badania z aptamerami przeciwko wirusowi gorączki doliny Rift, Dengii innymi arbowirusami. Ze względu na szybki wzrost populacji i różne odmiany wirusów, które są często oporne na standardowe leczenie terapeutyczne, istnieje wyraźna potrzeba opraco- 
wania nowych metod diagnostycznych, charakteryzujących się wysoką czułością i swoistością, umożliwiających wczesne i szybkie wykrywanie patogenu [27].

\section{DIAGNOSTYKA}

Standardowym narzędziem diagnostycznym jest wykrywanie przeciwciał IgG i IgM za pomocą testów serologicznych. Jednym z pierwszych testów stosowanych $\mathrm{w}$ diagnozowaniu HFRS w Europie i Azji był pośredni test immunoflouorescencyjny (ang. immunofluorescence assay; IFA) z wykorzystaniem komórek zakażonych hantawirusem. Używanie komórek zainfekowanych wirusami do testów serologicznych nie jest powszechnie stosowane, ponieważ wymaga to laboratoriów BSL-3 [15].

Najczęściej stosowanym testami serologicznymi są testy immunoenzymatyczne (ELISA). U wszystkich pacjentów obecne są przeciwciała IgM i IgG wykryte po wystąpieniu objawów krwotocznych, jednak czułość wykrywania tych przeciwciał może być mniejsza podczas etapu prodromalnego infekcji, utrudniając $\mathrm{w}$ ten sposób wczesną diagnozę. Również czułość i swoistość testów klinicznych w wykrywaniu hantawirusów w określonych obszarach mogą się różnić w zależności od antygenu $\mathrm{N}$ stosowanego jako antygen wychwytujący. W celu poprawy zdolności wykrywania i diagnostyki zakażeń hantawirusami opracowano testy na jednoczesne wykrywanie przeciwciał $\mathrm{w}$ stosunku do najważniejszych klinicznie hantawirusów Starego i Nowego Świata, a także testy na obecność wirusów krążących w określonych obszarach z użyciem homologicznego antygenu N. Większość testów obecnie wykorzystuje rekombinowane białko nukleokapsydowe N. Odpowiedzi przeciwciał przeciwko glikoproteinom Gn i Gc nie mają znaczenia diagnostycznego, ponieważ rozwijają się później i są znacznie mniej konserwatywne [31]. Poważną wadą jest jednak potencjalna krzyżowa reaktywność przeciwciał hantawirusa z innymi antygenami wirusowymi [19].

RT-PCR jest metodą, która umożliwia wykrycie wirusowego RNA we krwi, skrzepie lub tkankach uzyskanych w ciągu pierwszych 10 dni choroby. Jedyną wadą tej opartej na PCR metody jest to, że jest ona dodatnia tylko podczas wiremii. Ze względów praktycznych wykrywanie przeciwciał wirusowych za pomocą testu ELISA pozostaje aktualne w diagnostyce zakażeń [19].

\section{PODSUMOWANIE}

Wirusowe gorączki krwotoczne są ciężkimi chorobami zakaźnymi. Rozwój technik badawczych w dziedzinie mikrobiologii, immunologii i biologii molekularnej jak również pojawienie się nowych jeszcze nie sklasyfikowanych gatunków i odmian mikroorganizmów wywołujących choroby zakaźne sprawiają, że z każdym rokiem wykrywane są nowe czynniki biologiczne.

Hantawirusy to rodzaj wirusów RNA, z których co najmniej pięć - Puumala (PUUV), Dobrava-Belgrad (DOBV), Tula (TULV), Saarema (SAAV) i Seoul (SEOV) występuje w Europie [32]. Dokładny wpływ hantawirusów na zdrowie człowieka jak i patogeneza zakażenia nie zostały do koń- ca poznane. Ponadto istnieją hantawirusy i ich potencjalne rezerwuary, które nie zostały jeszcze dokładnie scharakteryzowane.

Zmiany środowiskowe mogą wpłynąć na rozkład geograficzny, ilość i dynamikę przemieszczania się gryzoni, a tym samym na epidemiologię chorób hantawirusowych [19]. Ze względu na zwiększoną międzynarodową turysty$\mathrm{kę} \mathrm{w}$ regionach, $\mathrm{w}$ których warunki sprzyjają przenoszeniu chorób zakaźnych, gorączki krwotoczne stały się poważnym wyzwaniem dla klinicystów i naukowców.

Aby poprawić profilaktykę zakażeń hantawirusowych, konieczne jest lepsze zrozumienie czynników i grup ryzyka, oraz skuteczności środków zapobiegawczych. Powinno to obejmować interdyscyplinarną współpracę (między specjalistami zdrowia publicznego, ekologami, lekarzami).

Niemniej jednak, hantawirusy pozostaną istotnym zagrożeniem dla zdrowia, a wywoływane przez nie choroby zasługują na uwagę naukowców i specjalistów zdrowia publicznego oraz zwiększoną świadomość kliniczną w zakresie wpływu zakażeń hantawirusowych na zdrowie publiczne.

\section{PIŚMIENNCTWO}

1. Albornoz A, Hoffmann AB, Lozach PY, Tischler ND (2016) Early bunyavirus-host cell Interactions. Viruses 8: 143

2. Sadkowska-Todys M, Dudek-Godeau D, Kamińska S (2015) Występowanie i utrzymywanie się zakażeń hantawirusami w populacji gryzoni w środowisku naturalnym - wyniki badań z terenu województwa podkarpackiego, w latach 2010-2012. Przegl Epidemiol 69: 395-399

3. Easterbrook JD, Klein SL (2008) Immunological mechanisms mediating hantavirus persistence in rodent reservoirs. PLoS Pathog 4: e1000172

4. Ermonval M, Baychelier F, Tordo N (2016) What do we know about how Hantaviruses interact with their different hosts? Viruses 8: 223

5. Zieliński A, Rosińska M, Gut W (2003) Gorączki krwotoczne - epidemiologia i klinika. Przegl Epidemiol 57: 639-654

6. Jiang H, Zheng X, Wang L, Du H, Wang P, Bai X (2017) Hantavirus infection: a global zoonotic challenge. Virol Sin 32: 32-43

7. Manigold T, Vial P (2014) Human hantavirus infections: epidemiology, clinical features, pathogenesis and immunology. Swiss Med Wkly 144: w13937

8. Avšič-Županc T, Saksida A, Korva M (2019) Hantavirus infections. Clin Microbiol Infect 21S: e6-16

9. Muyangwa M, Martynova EV, Khaiboullina SF, Morzunov SP, Rizvanov AA (2015) Hantaviral proteins: Structure, functions, and role in hantavirus infection. Front Microbiol 6: 1326

10. Jiang H, Du H, Wang LM, Wang PZ, Bai XF (2016) Hemorrhagic fever with renal syndrome: Pathogenesis and clinical picture. Front Cell Infect Microbiol 6: 1

11. Matthys V, Mackow ER (2012) Hantavirus regulation of type I interferon responses. Adv Virol 2012: 524024

12. Spiropoulou CF, Srikiatkhachorn A (2013) The role of endothelial activation in dengue hemorrhagic fever and hantavirus pulmonary syndrome. Virulence 4: 525-536

13. Krüger DH, Schönrich G, Klempa B (2011) Human pathogenic hantaviruses and prevention of infection. Hum Vaccin 7: 685-693

14. Krautkrämer E, Zeier M, Plyusnin A (2013) Hantavirus infection: an emerging infectious disease causing acute renal failure. Kidney Int 83: 23-27

15. Jonsson CB, Figueiredo LT, Vapalahti O (2010) A global perspective on hantavirus ecology, epidemiology, and disease. Clin Microbiol Rev 23: $412-441$ 
16. Terajima M, Ennis FA (2011) T cells and pathogenesis of hantavirus cardiopulmonary syndrome and hemorrhagic fever with renal syndrome. Viruses 3: 1059-1073

17. Korzeniewski K (2012). Wirusowe gorączki krwotoczne. Via Medica, Gdańsk

18. Jonsson CB, Hooper J, Mertz G (2008) Treatment of hantavirus pulmonary syndrome. Antiviral Res 78: 162-169

19. Llah ST, Mir S, Sharif S, Khan S, Mir MA (2018) Hantavirus induced cardiopulmonary syndrome: A public health concern. J Med Virol 90: 1003-1009

20. Mir MA (2010) Hantaviruses. Clin Lab Med. 30: 67-91

21. Bharadwaj M, Nofchissey R, Goade D, Koster F, Hjelle B (2000) Humoral immune responses in the hantavirus cardiopulmonary syndrome. J Infect Dis 182: 43-48

22. Goeijenbier M, Wagenaar J, Goris M, Martina B, Henttonen H, Vaheri A, Reusken C, Hartskeerl R, Osterhaus A, Van Gorp E (2013) Rodent-borne hemorrhagic fevers: under-recognized, widely spread and preventable - epidemiology, diagnostics and treatment. Crit Rev Microbiol 39: 26-42

23. Rasmuson J, Lindqvist P, Sörensen K, Hedström M, Blomberg A, Ahlm C (2013) Cardiopulmonary involvement in Puumala hantavirus infection. BMC Infect Dis 13: 501
24. Krautkrämer E, Zeier M (2014) Old World hantaviruses: aspects of pathogenesis and clinical course of acute renal failure. Virus Res 187: 59-64

25. Piszczyk J (2016) Wirusowe gorączki krwotoczne czy gorączka Zachodniego Nilu - niespodzianka w podróży. Diagnostyka Lab 52: 5156

26. Krüger DH, Ulrich R, Lundkvist AA (2001) Hantavirus infections and their prevention. Microbes Infect 3: 1129-1144

27. Wandtke T, Woźniak J, Kopiński P (2015) Aptamers in diagnostics and treatment of viral infections. Viruses 7: 751-780

28. Fhogartaigh CN, Aarons E (2015) Viral haemorrhagic fever. Clin Med (Lond). 15: 61-66

29. Dong J, Olano JP, McBride JW, Walker DH (2008) Emerging pathogens: challenges and successes of molecular diagnostics. J Mol Diagn 10: 185-197

30. Racsa LD, Kraft CS, Olinger GG, Hensley LE (2016) Viral hemorrhagic fever diagnostics. Clin Infect Dis 62: 214-219

31. Maes P, Clement J, Gavrilovskaya I, Van Ranst M (2004) Hantaviruses: immunology, treatment, and prevention. Viral Immunol17: 481-497

32. https:/ / ecdc.europa.eu/en/hantavirus-infection (dostęp: 12.10.2020)

\section{Infections with hantavirus, with particular emphasis on the European population and their clinical picture against other hemorrhagic fevers}

\section{mgr. Kamila Julia Stopnicka, dr n. med. Szymon Walter de Walthoffen, dr hab. n. med. Tomasz

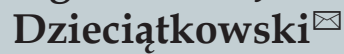

Chair and Department of Medical Microbiology, Medical University of Warsaw, Chalubinskiego 5, 02-004 Warsaw, Poland

$\square^{\circledR}$ Corresponding author: tdzieciatkowski@wum.edu.pl

Keywords: hantaviruses, viral infections, heamorrhagic fever, diagnostic methods, zoonoses

\section{ABSTRACT}

Hantaviruses belong to Bunyaviridae family. They are the cause of two diseases dangerous for human: in Asia and Europe hemorrhagic fever with renal syndorme; in Americas hantavirus cardiopulmonary syndrome. Most of hantaviruses are being spread by rodents, however other small mammals also can be the reservoir. Hantavirus infections are difficult to distinguish, because of the similar clinical symptoms to those caused by other hemorrhagic fever viruses. 